\title{
THE TOTAL ENERGY REQUIREMENT IN DIABETES MELLITUS
}

\author{
BASED ON OBSERVATIONS WITH THE PETTENKOFER-VOIT CHAMBER *
}

EUGENE F. DUBOIS, M.D.

NEW YORK

AND

BORDEN S. VEEDER, M.D.

PHILADELPHIA

Although the work on the various phases of metabolism in diabetes mellitus has become voluminous, there are but few records of the respiratory metabolism and of the total energy requirement. The statement commonly made in text-books and literature on the subject, that there is practically no change from the normal, is based almost entirely on the observations made in a severe case of diabetes by Pettenkofer and C. Voit $^{1}$ in 186\%. In the original article no caloric estimations were made and incorrect conclusions were drawn, which were subsequently corrected by C. Voit ${ }^{2}$ and F. Voit. ${ }^{*}$ Graham Lusk, ${ }^{4}$ using unpublished figures obtained from Erwin Voit, gives the caloric determination of the same case as 34 calories per kilo. None of these authors give the figures of the reckoning. Ebstein, ${ }^{5}$ in 1898 , determined the twenty-four-hour carbon dioxid output in a case of severe diabetes, but did not go into the question of energy requirement. In his article he says that Lehman will consider the details in a later publication, but we have failed to find any such article or to find any reference to it in literature. Iivierato ${ }^{6}$ also made some tests in cases of diabetes, but his work has been considered so unsatisfactory that other investigators have refused to draw conclusions from it.

* From the Laboratories of the II Medical Clinic, Kgl. Charite, Berlin.

1. Pettenkofer and Voit: Ueber den Stoffwechselverbrauch in der Zucherharnruhr. Ztsehr. f. Biol., 1867, iii, 380.

2. Voit, C.: Physiologie des Stoffwechsels, 1881, p. 328.

3. Voit, F.: Ueber den Stoffwechsel bei Diabetes Mellitus. Ztschr. f. Biol., 1892, xxix, 129.

4. Lusk, Graham: Ztschr. f. Biol., 1890, xxvii, 478.

5. Ebstein: Beitrag zum respiratorischen Gaswechsel bei der Zuckerkrankheit. Deutsch. Med. Wehnschr., 1898, xxiv, 101.

6. Livierato, P. E.: Schwankungen der von Diabetiker ausgeschiedenen Kollensäure. Arch. f. exper. Path. u. Pharmakol., 1889, xxv, 161. 
Falta, ${ }^{7}$ in a recent publication, gives the results of three cases of diabetes observed together with Benedict and Joslin in which an AtwaterBenedict chamber was used. He gives no details except a statement that two of the cases were severe, and that the metabolism was determined in a condition of hunger and with observations lasting six hours. His figures vary from 30 to 35 "Kal. pro St."; as this would mean about 785 calories in twenty-four hours, we imagine he means "Kal. pro Kilo." Observations have been made with the Zuntz-Geppert apparatus by many workers. Leo, ${ }^{8}$ Weintraud and Laves, ${ }^{9}$ Nehring and Schmoll, ${ }^{10}$ Robin and Binet, ${ }^{11}$ Magnus-Levy, ${ }^{12}$ and others. The Zuntz-Geppert apparatus, however, only determines the direct exchange of oxygen and carbon dioxid for short spaces of time-usually for ten or fifteen minutes in each of several consecutive hours. This gives much valuable information, particularly in regard to the utilization of various foodstuffs, but, on account of the short period of investigation and the large chances of technical error, it is impossible to make reliable deductions as to carbon dioxid output for twenty-four hours. This can be seen by comparing the figures of the various investigators above mentioned.

At the suggestion of Herr-Privat-Docent Dr. Theodor Brugsch, to whom we wish to acknowledge our deep indebtedness for his valuable help and advice, we undertook a series of three observations with the Pettenkofer-Voit chamber, using the more modern methods of chemical analysis of food, feces and urine. Our object was to ascertain whether or not cases of diabetes mellitus show a variation from the normal in the total energy requirement and the twenty-four-hour carbon dioxid output. The first observation was on a normal individual weighing $\% 0.1$ kilos as a control; the second on a patient weighing 70.4 kilos, with severe diabetes, acidosis and large sugar excretion; and the third on a patient weighing 68 kilos, with mild diabetes. As all three were of nearly the same weight and stature, the questions of variation due to body surface and weight were minimized.

7. Falta: Ueber das Respirationskalorimeter in Boston. Wien. klin. Wehnschr., 1909, xxii, 565.

8. Leo, H.: Ueber den respiratorischen Stoffwechsel beim Diabetes mellitus. Ztschr. f. klin. Med., 1891, xix, sup. Heft, 101.

9. Weintraud, W, and Laves, E.: Ueber den respiratorischen Stoffwechsel im Diabetes Mellitus. Ztschr. f. physiol. Chem., 1894, xix, 603.

10. Nehring, O., and Schmoll, E.: Ueber den Einfluss der Kohlehydrate auf den Gaswechsel des Diabetikers. Ztschr. f. klin. Med., 1897, xxxi, 59.

11. Robin and Binet: Exchanges respiratoires dans le diabète. Arch. gên. de méd., 1898, x, 283.

12. Magnus-Levy: Respirations-versuche an liabetischen Mensehen. Ztschr. f. klin. Med., 1905, lvi, 83. 
The Pettenkofer-Voit chamber was the one used and described by Sieyrer, ${ }^{13}$ and the methods, which were the same for all three cases, followed his very closely. First the chamber was tested by several normal candle burnings. Then, before each subject was put into the chamber, his nitrogen excretion was determined for several days in order to be able to give sufficient protein food to bring about an approximate nitrogen balance. Enough fat and carbohydrate were added to cover the probable caloric needs and water was allowed ad libitum. In each case the diet was practically the same as that which the subject had been having for the previous week. On the morning of the observation, after several hours of fasting, a meal was given and also a $0.3 \mathrm{gm}$. carmine powder. Then the subject was put in the chamber for twenty-two hours, all reckonings being corrected for a twenty-four-hour basis. While the subject was in the chamber two more meals were given, the last one being at least five hours before the end of the observation. During practically the whole time the patient was in bed in a condition of Zimmerruhe, doing no kind of work except the movements of eating, reading and turning in bed. Three hours after leaving the chamber a meal was given, together with a second carmine powder.

The food given was made up in double quantities and divided equally in two portions by weight, one being given to the subject of the investigation and the other being analyzed. The feces were collected from the appearance of and including the first carmine powder, up to the appearance of the second. The specimen of urine was collected in the usual way during the twenty-four-hour period of the observation. Food and feces were dried over a water bath for six days and then for a short time in a drying oven at $60^{\circ}$. The amount of nitrogen was obtained by Kjeldahl's method and protein calculated by multiplying by 6.25 and protein carbon by multiplying by 3.28. A weighed portion of each, food and feces, was extracted with ether (feces method of $\mathrm{Brugsch}^{14}$ ) and the amount of fat obtained. Carbohydrate determinations were made in most cases by boiling with 2 per cent. hydrochloric acid and alcohol and titrating the sugar, in some cases by subtracting the protein carbon and the fat carbon from total carbon. The carbon of the fat was obtained by elementary analysis and a portion of the food from which the fat had been extracted was burned, thus obtaining the total carbon present. Ash was obtained by Kjeldahl's method and the amount of carbon by elementary analysis.

13. Steyrer: Ueber den Stoff und Energieumsatz bei Fieber, u. s. w. Ztschr. f. exper. Path. u. Therap., 1907, iv, 720.

14. Brugseh: Fett bestimmung in den Fäzes. Brugseh and Schittenhelm, Lehrbuch klinischer Untersuchungs methoden, 1908, p. 576. 
Sugar was determined by Kumagawa's ${ }^{15}$ modification of Pavy's method and acetone by the method of Huppert-Messinger. ${ }^{19}$ Control analyses were made in all cases, in some instances by Dr. E. B. Leech of Manchester, England. In determining the caloric values the following generally accepted factors of Rubner were used:

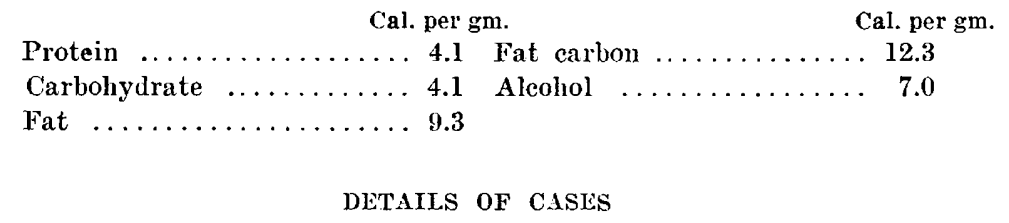

Case 1.-June 3-4, 1909; D., physician, aged 27, weight $70.1 \mathrm{kilos,} \mathrm{normal.}$ In the following tabular matter, units are grams, unless otherwise specified:

\begin{tabular}{|c|c|c|c|}
\hline \multicolumn{4}{|c|}{ Food } \\
\hline Beefsteak ..... & 120.0 & Sugar & 30.0 \\
\hline Rice $\ldots \ldots \ldots \ldots \ldots$ & 100.0 & Bread & 200.0 \\
\hline Butter $\ldots \ldots \ldots$ & 150.0 & Milk & $\ldots \ldots 1000.0$ \\
\hline
\end{tabular}

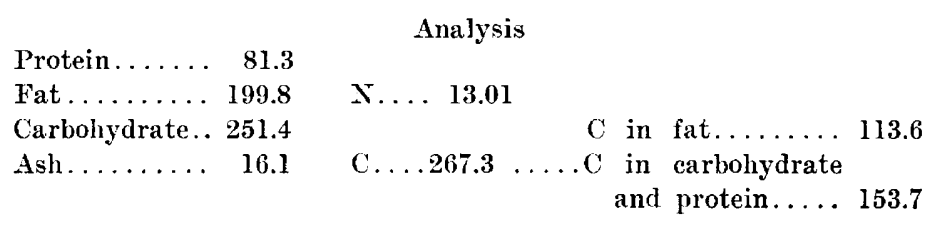

Feces

Weight dried $\ldots \ldots \ldots \ldots \ldots \ldots \ldots \ldots \ldots \ldots \ldots \ldots \ldots \ldots . \ldots \ldots$

Analysis

\begin{tabular}{|c|c|c|}
\hline Protein.... . . . . . . 7.9 & & \\
\hline Fat. . . $\ldots \ldots \ldots \ldots \ldots$ & $\mathrm{X} \ldots 1.27$ & \\
\hline Carbohydrate.......... 4.01 & & \\
\hline Ash............... 5.1 & C $\ldots .9 .8$ & \\
\hline URIN & & \\
\hline Quantity. & & 1600 c.c. \\
\hline Albumin.............negative & X..12.8 & \\
\hline Sugar $\ldots \ldots \ldots \ldots$ negative & C . . . 10.50 & $\mathrm{C}: \mathrm{N} \ldots 0.825$ \\
\hline $\mathrm{CO}_{2}$ output for twenty-four hours... & $\ldots \ldots \ldots$ & $\ldots 783.8 \mathrm{gm}$. \\
\hline C output for twenty-four hours.. & & .. $213.77 \mathrm{gm}$. \\
\hline
\end{tabular}

15. Kumagawa: Salkowski's Festschrift, 1904, p. 211.

16. Huppert-Messinger: Brugseh and Schittenhelm, Lehrbuch klinischer Lntersuchungs methoden, 1908, p. 510. 
Food. Feces. Absorbed. Urine. Balance.

\begin{tabular}{|c|c|c|c|c|c|c|}
\hline Protein & $\begin{array}{l}\text { Food. } \\
810.3\end{array}$ & $\begin{array}{c}\text { Feces. } \\
7.9\end{array}$ & $\begin{array}{c}\text { Absorbed. } \\
73.4\end{array}$ & $\begin{array}{c}\text { Urine. } \\
\ldots \ldots\end{array}$ & $\begin{array}{c}\text { Balance. } \\
\ldots .\end{array}$ & $\begin{array}{c}\text { olized. } \\
80.0\end{array}$ \\
\hline Protein $\mathrm{N}$ & 13.01 & 1.27 & 11.74 & 12.8 & -1.06 & 12.8 \\
\hline Protein $\mathrm{C} \ldots \ldots \ldots \ldots \ldots \ldots$ & 42.67 & 4.16 & 38.51 & $\ldots$ & -3.47 & 41.98 \\
\hline Protein calories $\ldots \ldots \ldots \ldots \ldots$ & $\ldots$ & $\ldots$ & . & & $\ldots \ldots$ & 328.0 \\
\hline Fat $\ldots$ & 199.8 & 6.0 & 193.8 & & & \\
\hline Fat $\mathrm{C}$ & 113.6 & 3.86 & 109.74 & & +36.64 & 73.10 \\
\hline Fat calorie & $\ldots$ & $\ldots$ & $\ldots$ & & . & 899.1 \\
\hline ydrate & 251.4 & 4.01 & 247.39 & & & 247.39 \\
\hline 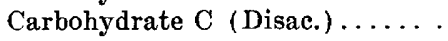 & 12.63 & $\cdots$ & 12.63 & & $\ldots$. & 109.25 \\
\hline 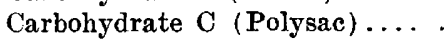 & 98.4 & 1.78 & 96.62 & & $\ldots$ & \\
\hline Carbohydrate calories......... & $\ldots$ & $\ldots$ & $\ldots \ldots$ & & $\ldots$ & 1063.77 \\
\hline
\end{tabular}

\section{SUMMIARY}

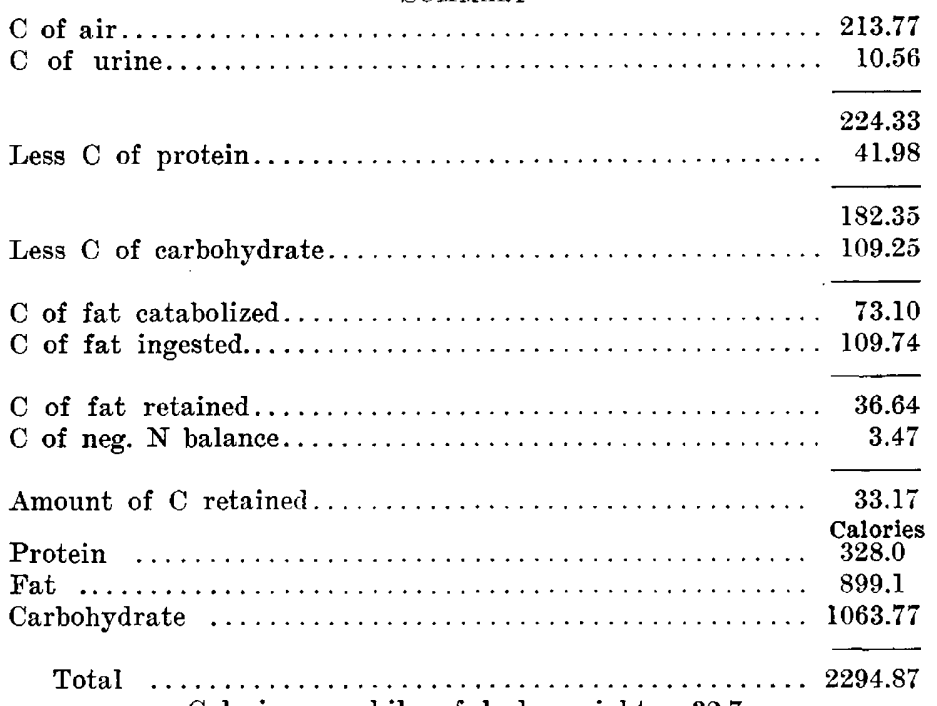

Calories per kilo of body weight. 32.7

CASE 2.-June 10-11, 1909: S. G., dental student, aged 23, weight 70.4 kilos, with severe diabetes. Two years ago it was found that the patient had diabetes mellitus with 2.5 per cent. of sugar but no acidosis, the sugar disappearing from the urine on the withdrawal of carbohydrates from the diet. About six months before our observation he underwent two minor operations under chloroform anesthesia. Following the operation acetone and diacetic acid appeared in the urine, and the acidosis has been a constant factor since. The patient has been in the hospital for general treatment for about three weeks. . On ordinary diet sugar amounts to 2 to 5 per cent., acetone trace. On a carbohydrate-free diet sugar is present. Acetone and diacetic acid are present in small amounts, clearing up temporarily after a few oatmeal days. Hyperglycemia, 0.3 per cent. Heart and lungs normal. General condition of patient's nutrition and musculature good. No obesity.

FooD

Chopped steak ....... $\mathbf{1 5 0 . 0}$ Thin oatmeal gruel..... 385.0

Ham $\ldots \ldots \ldots \ldots \ldots \ldots .49 .0$ Bread $\ldots \ldots \ldots \ldots \ldots \ldots .66 .0$

Sausage $\ldots \ldots \ldots \ldots \ldots .25 .8$ Soup (veg.) ......... 440.0

Bacon ........... 12.5 Cognac ........... 40.0

Butter ............................. 41.6 cups 


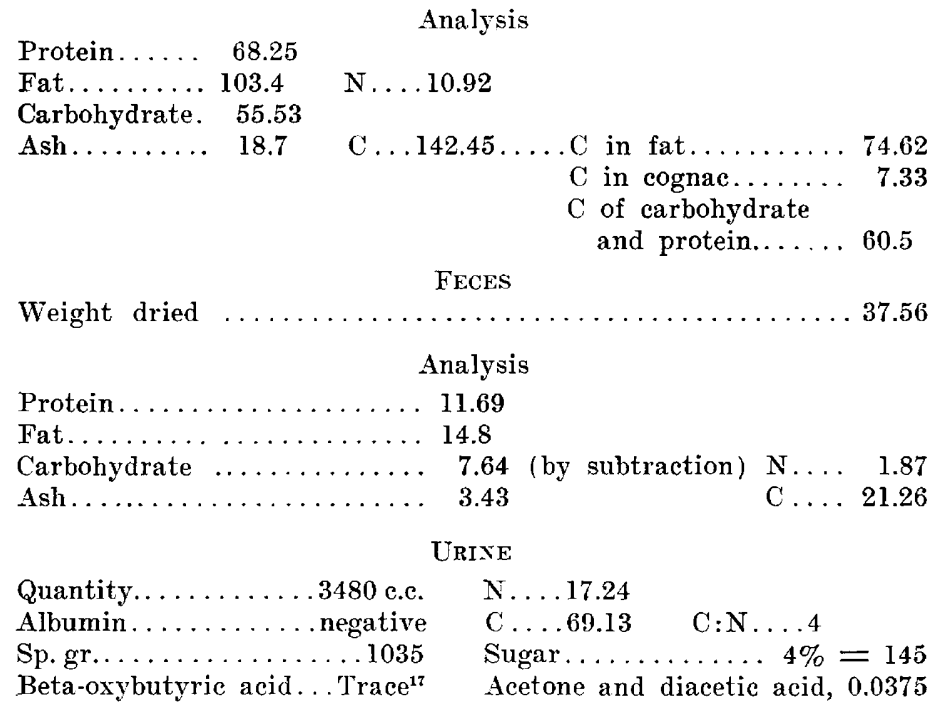

$$
\text { AIR }
$$

$\mathrm{CO}_{2}$ output for twenty-four hours ........... $748.8 \mathrm{gm}$.

C output for twenty-four hours............ $204.2 \mathrm{gm}$.

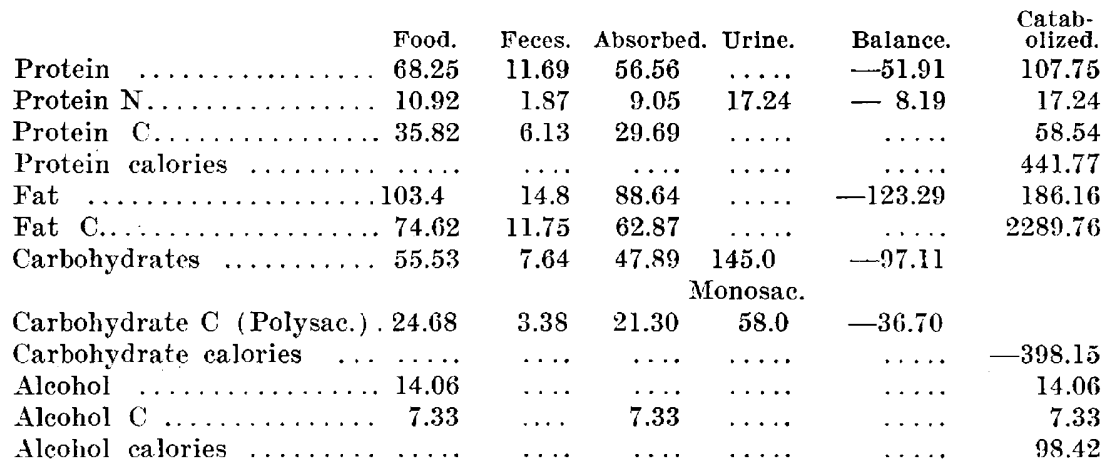

\section{SU,MMARY}

In reckoning the metabolism in this case the altered relations due to the excessive excretion of sugar must be taken into consideration. The amount of carbohydrate ingested was more than balanced by the amount excreted and is therefore not taken into the reckoning, since it was not available for energy. We find that $21.30 \mathrm{gm}$. of carbon were ingested in the form of carbohydrates, while 58.0 were excreted, making the carbon of the negative carbohydrate balance

17. Several determinations of the beta-oxybutyric acid were made with results showing a technical error. The amount in each case was very small, and we decided the error would be less in ignoring its presence than in using a mean of the determinations. The amount was so little that it would make but slight and unimportant changes in the final results. 
36.70. This amount of carbon in the sugar must have been made up from the protein, and hence must be added to the carbon in the air, and the carbon of the non-carbohydrate part of the urine, in order to obtain the total amount of carbon in the metabolism of the protein, alcohol and fat.

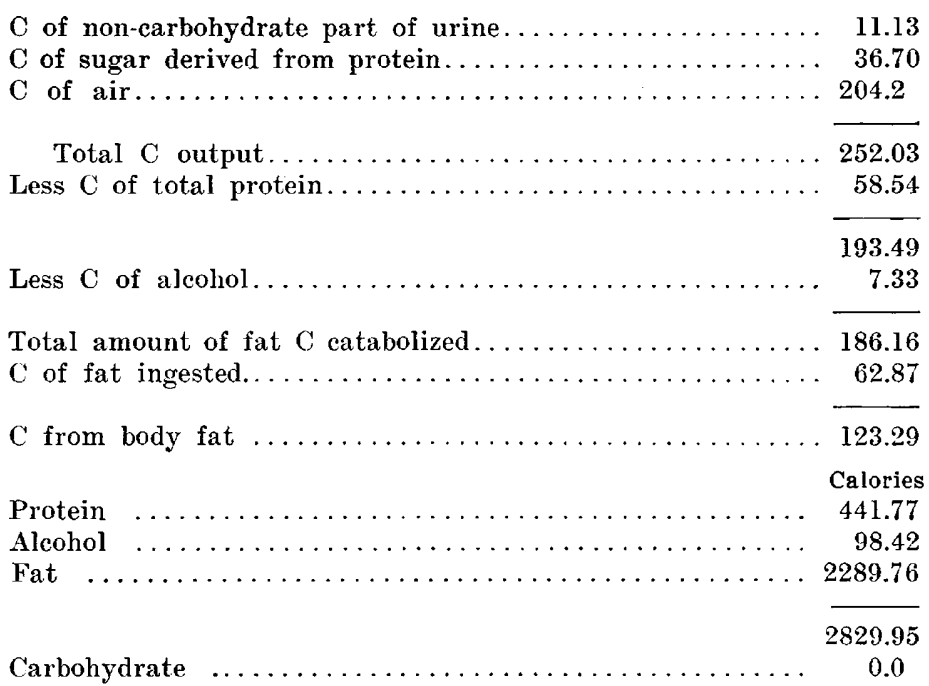

From this must be deducted the heat loss of the sugar built up, as we have added above the carbon of sugar derived from body protein.

Total calories

2453.78

Calories per kilo of body weight. 34.8

It will be noted that the diabetic patient excreted $4.4 \mathrm{gm}$. more nitrogen than the normal individual. Rubner ${ }^{18}$ states that 28.5 per cent. of this excess equaling 0.5 calory per kilo is not utilized and hence should be subtracted from the total, leaving the figure of 34.3 .

CASE 3.-July 3-4, 1909: Max M., government official, aged 39, weight 68 kilos, with mild diabetes. For several years patient has had a mild diabetes designated by his physician as "kidney diabetes." We personally had no opportunity to make protracted observations, but it is said there is always a small amount of sugar present in the urine varying from 0.5 to $1.5 \%$, regardless of diet. We regret not having been able to go more deeply into the pathogenesis and clinical aspects. The urine averages about 2 liters daily, and patient, with but slight carbohydrate restriction, showed 0.52 per cent. of sugar before the observation, on the only control sugar test made by us. The patient's general health, condition of nutrition and development were good and he was able to do his work without the slightest difficulty. He was not a patient in the Charité, but underwent the observation as a matter of courtesy to Dr. Brugseh.

18. Rubner: Gesetze des Energieverbrauchs, 1902. 
Food

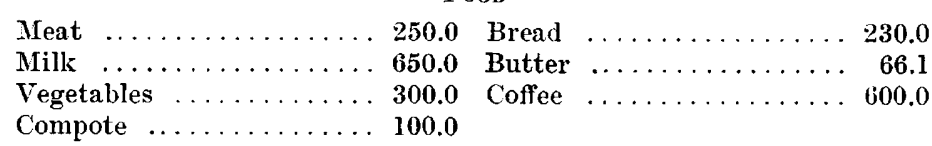

Protein....... 111.25
Fat......... 105.2

Carbohydrates. . 190.20

Analysis

$$
\text { N. . . } 17.8
$$

C..233.49...C in fat.... 86.13

$\mathrm{C}$ in protein and carbohydrate 147.36

Fecks

Weight dried

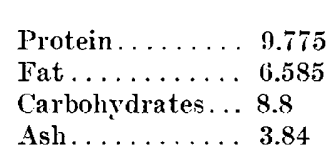

URIXE

Quantity

Albumin............negative

Acetone............negative

Beta-oxybutyric acid... negative

\begin{tabular}{|c|c|}
\hline ז...9.17 & \\
\hline $\begin{array}{l}\text { C...8.72 } \\
\text { Sugar.... }\end{array}$ & $\begin{array}{c}\mathrm{C}: \mathrm{N} \ldots 0.96 \\
\ldots 0.4 \%=\end{array}$ \\
\hline
\end{tabular}

AIR

$\mathrm{CO}_{2}$ output for twenty-four hours. $778.41 \mathrm{gm}$. C output for twenty-four hours $212.3 \mathrm{gm}$.

\begin{tabular}{|c|c|c|c|c|c|c|}
\hline Protein & $\begin{array}{c}\text { Food. } \\
111.25\end{array}$ & $\begin{array}{l}\text { Feces. } \\
9.875\end{array}$ & $\begin{array}{c}\text { Absorbed. } \\
101.375\end{array}$ & $\begin{array}{c}\text { Urine. } \\
\ldots . .\end{array}$ & $\begin{array}{c}\text { Balance. } \\
\ldots . .\end{array}$ & $\begin{array}{r}\text { Catab- } \\
\text { olized. } \\
52.62\end{array}$ \\
\hline Protein N.. & 17.8 & 1.58 & 16.22 & 8.42 & +7.8 & 8.42 \\
\hline Protein C & 58.38 & 5.08 & 53.30 & $\ldots$ & $\ldots \ldots$ & 27.36 \\
\hline Protein calories & & & & . & & 215.75 \\
\hline Fat & 105.2 & 6.585 & 98.615 & & -27.136 & \\
\hline Fat $\mathrm{C} \ldots$ & 86.13 & 5.185 & 80.945 & $\cdots$ & $\ldots \ldots$ & 108.08 \\
\hline Fat calories $\ldots \ldots \ldots \ldots$ & $\ldots \ldots$ & $\cdots$ & & $\cdots$ & & 1329.48 \\
\hline Carbohydrate $\ldots \ldots \ldots \ldots$. & 190.25 & 8.8 & 181.45 & 7.76 & & 173.69 \\
\hline Carbohydrate C.......... & 88.98 & 3.4 & 85.58 & 3.7 & $\ldots \ldots$ & 82.48 \\
\hline Carbohydrate ealories .... & $\ldots \ldots$ & $\ldots$ & $\ldots \ldots$ & $\ldots$ & $\ldots \ldots$ & 712.13 \\
\hline
\end{tabular}

\section{SUMMARY}

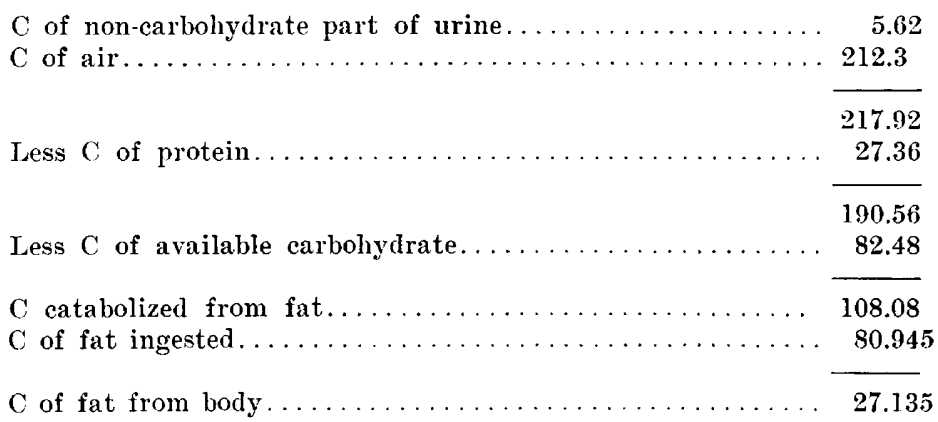




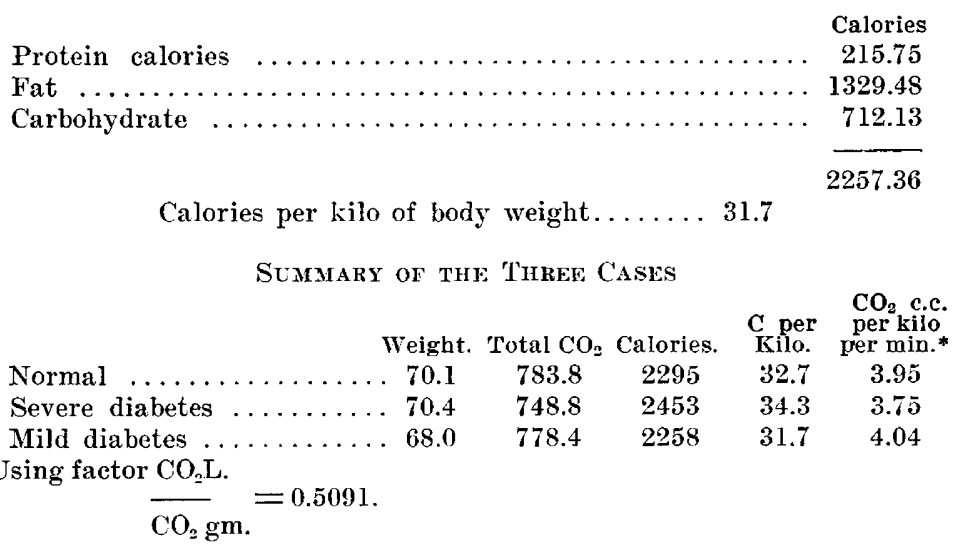

Comparing a number of cases by different observers of normal individuals of similar weight and under similar conditions, as given by Magnus-Levy, ${ }^{19}$ it is seen that all three of our cases are close to the figures for normal individuals.

XORMAL INDIVIDUALS AT REST

$\begin{array}{cccl}\text { Weight. } & \text { Calories. } & \text { C Per Kilo. } & \begin{array}{l}\text { Observer. } \\ \text { Siven }\end{array} \\ 64.8 & 1918 & 29.6 & \text { Atwater } \\ 65.0 & 2136 & 32.9 & \text { Atwater } \\ 70.0 & 2279 & 32.5 & \text { Atwater } \\ 70.0 & 2278 & 32.5 & \text { Clopat } \\ 73.6 & 2101 & 28.9 & \text { Senden \& T. } \\ 72.7 & 2269 & 31.2 & \text { Ranke } \\ 73.3 & 2198 & 30.0 & \ldots \ldots \ldots\end{array}$

In neither the severe nor the mild case is there sufficient variation from the normal to warrant any statement of a decreased or increased energy requirement.

COMPARISON OF FIGURES OF VARIOUS OBSERVERS ON DIABETES

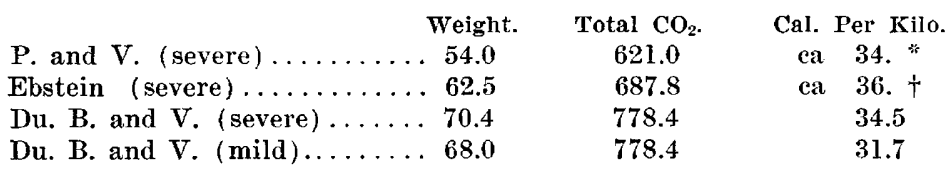

* Figures as given by Graham Lusk-no original reckoning.

† Figures as given by Magnus-Levy-no original reckoning.

In the case of Pettenkofer and Voit ${ }^{1}$ we have selected the observation in which the food and conditions seem nearest to those of our case. The original investigations extended over a long period of time in which there

19. Magnus-Levy: In Von Noorden's Handbuch der Pathologie des Stoffwechsels, 1906, i, 291. 
was a loss in weight, and so a slight difference will be found betwern our figures and some others published, such as Magnus-Levy's, in which a mean of five observations was taken. The different caloric estimations of different authors for Pettenkofer and Voit's work varies between 33 and 36 in the same case. Ebstein gives no original figures for the calories. It will be noted that all three of the severe cases are at the extreme upper limit of what is considered the normal metabolism.

The only method by which we can make a comparison with the ZuntzGeppert apparatus is by comparing the $\mathrm{CO}_{2}$ output in cubic centimeters per kilo per minute.

Our figures are as follows:

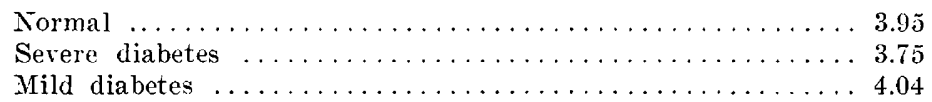

The average of twelve other cases of diabetes cited by Von Noorden ${ }^{20}$ is 3.93 , which is within the limits for a normal individual.

\section{CONCI,USIONS}

The total energy requirement of cases of diabetes does not vary from the normal. In addition to the 31-35 calories required for the normal individual at rest, the diabetic should be given enough extra calories to cover the loss of sugar in the urine. If this is not done there is a breaking down of the body protein and fat.

Presbyterian Hospital, New York-2033 Locust Street, Philadelphia.

20. Von Noorden: Diabetes Meliitus. Handbuch der Pathologie des Stoffwechsels, 1907, ii, 46 . 